\title{
Adipose tissue as an endocrine organ: role of leptin and adiponectin in the pathogenesis of cardiovascular diseases
}

\author{
A. Fortuño ${ }^{1}$, A. Rodríguez ${ }^{2}$, J. Gómez-Ambrosi ${ }^{2}$, G. Frühbeck ${ }^{2,3}$ and J. Díez ${ }^{1,4}$ \\ ${ }^{1}$ Division of Cardiovascular Pathophysiology, Centre for Applied Medical Research, \\ 31008 Pamplona, ${ }^{2}$ Metabolic Research Laboratory, School of Medicine, ${ }^{3}$ Department of \\ Endocrinology, University Clinic and ${ }^{4}$ Department of Cardiology and Cardiovascular \\ Surgery, University Clinic. Pamplona, Spain
}

(Received on February 18, 2003)

A. FORTUÑO, A. RODRÍGUEZ, J. GÓMEZ-AMBROSI, G. FRÜHBECK and J. DÍEZ. Adipose tissue as an endocrine organ: role of leptin and adiponectin in the pathogenesis of cardiovascular diseases (minireview). J. Physiol. Biochem., 59 (1), 51-60, 2003.

Obesity, the most common nutritional disorder in industrial countries, is associated with increased cardiovascular mortality and morbidity. Nevertheless, the molecular basis linking obesity with cardiovascular disturbances have not yet been fully clarified. Recent advances in the biology of adipose tissue indicate that it is not simply an energy storage organ, but also a secretory organ, producing a variety of bioactive substances, including leptin and adiponectin, that may influence the function as well as the structural integrity of the cardiovascular system. Leptin, besides being a satiety signal for the central nervous system and to be related to insulin and glucose metabolism, may also play an important role in regulating vascular tone because of the widespread distribution of functional receptors in the vascular cells. On the other hand, the more recently discovered protein, adiponectin, seems to play a protective role in experimental models of vascular injury, in probable relation to its ability to suppress the attachment of monocytes to endothelial cells, which is an early event in the atherosclerotic process. There is already considerable evidence linking altered production of some adipocyte hormones with the cardiovascular complications of obesity. Therefore, the knowledge of alterations in the endocrine function of adipose tissue may help to further understand the high cardiovascular risk associated with obesity.

Key words: Adipocytes, Adiponectin, Cardiovascular diseases, Leptin, Obesity.

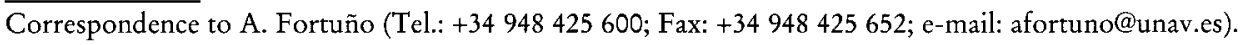




\section{Obesity-associated cardiovascular diseases}

Diabetes mellitus, hyperlipidemia, hypertension and atherosclerosis have been recently defined as typical lifestylerelated diseases. A common background of these diseases is overnutrition and its consequence, obesity. An individual with a body mass index (BMI) greater than 30 $\mathrm{kg} / \mathrm{m}^{2}$ is four times more likely to suffer from nearly all of the common cardiovascular diseases (stroke, coronary artery disease, congestive heart failure, cardiomyopathy, and possibly arrhythmia/sudden death) than an individual with a BMI of 25 $\mathrm{kg} / \mathrm{m}^{2}$ or less $(3,21)$. So, obesity is an independent risk factor of cardiovascular diseases (CVD). Previous epidemiological studies of obesity have documented a modest association of obesity and risk of CVD, especially in younger age groups. Weight gain during young adult life may be one of the most important determinants of cardiovascular risk factors. It is now well accepted that inflammation is a major component of atherosclerosis. Moreover, adipose tissue is now recognized as a source of inflammatory mediators, with production of cytokines such as tumor necrosis factor (TNF)- $\alpha$ and interleukin (IL)-6 (59). It appears likely, that the relationship between obesity, insulin resistance and atherosclerosis may depend, at least in part, on the increased production and release of these inflammatory mediators from adipose tissue. Obesity is a prothrombotic state, in part due to a secondary effect of insulin resistance; this is a contributing factor to elevated risk of coronary heart disease and stroke (43). Pulmonary thromboembolic disease also occurs at higher rates in the obese, probably because of venous stasis (30).

As it has been resumed, the effects of obesity on cardiovascular health and dis- ease are many, but one of the most profound is hypertension. Epidemiological studies suggest that up to $50 \%$ of obese individuals have concomitant hypertension (38). Studies in humans show that weight gain raises blood pressure and that weight loss reduces blood pressure in both normotensive and hypertensive patients (49). Obesity also appears to change the normal circadian variation of blood pressure. In a recent study, it has been described that up to $70 \%$ of obesehypertensive subjects failed to show an appropriate fall in both systolic and diastolic pressures during sleep (74). The hemodynamic profile of obese subjects is characterised by high intravascular volume, high cardiac output, and high peripheral resistance $(27,48)$. Because heart rate remains unchanged, the increase in cardiac output in response to the elevated metabolic requirements and expanded intravascular volume occurs chiefly through increased stroke volume. Moreover, cellular metabolism of cations and other molecules may be altered in obesity and lead to changes in vascular responsiveness (62). Among these molecules, insulin has been shown to be a vasodilator that regulates peripheral vascular resistance. Insulin not only inhibits voltage-gated $\mathrm{Ca}^{2+}$ influx, but also stimulates glucose transport and phosphorylation of glucose to glucose-6-phosphate, which further activates $\mathrm{Ca}^{2+}$-ATPase transcription and increases cellular $\mathrm{Ca}^{2+}$ efflux. Both actions result in a net decrease in intracellular $\mathrm{Ca}^{2+}$ and, therefore, decreased vascular resistance. These effects are blunted in obesity due to insulin resistance, leading to increased vascular resistance (78). Besides, obesity is often accompanied with structural changes in peripheral resistance vessels $(8$, 62). 


\section{Adipose tissue as an endocrine organ}

A main characteristic of obesity is the exaggerated augmentation of adipose tissue. Recent advances in the biology of adipose tissue have revealed that it is not simply an energy storage organ $(22,29)$. The adipocyte must not be considered as an inert depot for storing fuel as lipid, to be released only during times of hardship such as fasting or starvation. In fact, it also secretes hormones in response to specific extracellular stimuli or changes in metabolic status (63). Most of these hormones act in an autocrine/paracrine manner to regulate adipocyte metabolism; upon secretion into the blood stream, they act as endocrine signals at multiple distant sites to regulate energy homeostasis (23). Some of these varieties of biologically active molecules perform diverse functions, but seem to share some structural properties of cytokines. They have been conceptualised collectively as "adipocytokines/adipokines" (69). Some of these proteins are inflammatory cytokines, some play a role in lipid metabolism, while others are involved in vascular homeostasis or the complement system (Table I). Thus, adipose cells play a more dynamic role than previously recognised in physiological mechanisms (50). In the present review, the role of adiponectin, a novel adipose-specific gene product, and leptin, the obese $(a b)$ gene product, will be discussed.

\section{Adiponectin}

Adiponectin, the gene product of the adipose most-abundant gene transcript 1 (apM1) gene, is an adipocyte-derived plasma protein identified in 1995 from the human cDNA project targeting on adipose tissue. Adiponectin is a 244-amino acid protein with high structural homolo- gy to collagen VIII, $\mathrm{X}$ and complement C1q $(44,55)$. This protein was also identified independently by three other groups using different approaches, and was named as gelatin-binding protein (GBP28) (51), adipocyte complementrelated protein of $30 \mathrm{kDa}$ (Acrp30) (64) or AdipoQ (35). Acrp30 and AdipoQ were isolated from differentiated adipocytes and they are the mouse counterpart of adiponectin. It is expressed specifically in white adipose tissue and exists abundantly in the plasma, approximately $0.01 \%$ of total plasma protein $(5,34)$. Its secretion is modulated by insulin, pointing to the possibility that the expression is regulated by the nutritional state $(7,76)$. Clinically, plasma adiponectin concentrations range from 3 to $30 \mu \mathrm{g} / \mathrm{ml}$ and are decreased in patients with obesity (5), non-insulindependent diabetes mellitus (33), insulin resistance (75) and dyslipidemia (46). The incidence of cardiovascular death was higher in patients with low plasma adiponectin compared with those with higher adiponectin levels (81). Decreased plasma adiponectin concentrations have been suggested as an indicator of microangiopathy in type 2 diabetic patients (33). The degree of hypoadiponectinemia correlated with the incidence of fatal heart ischemia in the subjects with chronic heart failure (81). Furthermore, it has been recently published that male patients with hypoadiponectinemia $(<4.0 \mu \mathrm{g} / \mathrm{ml})$ had a significant 2-fold increase in coronary artery disease prevalence, independent of other well-known coronary artery disease risk factors (40). These findings suggest that the measurement of the adipocytespecific plasma protein adiponectin level could be helpful to evaluate coronary artery disease risk. Therefore, understanding the clinical significance of plasma adiponectin may be helpful in preventing 
Table I. Factors secreted by adipose tissue.

\begin{tabular}{|c|c|}
\hline Factor & References \\
\hline Acylation stimulating protein (ASP) & Cianflone et al.1989 (17) \\
\hline Adiponectin & $\begin{array}{l}\text { Hu et al. } 19,96(35) \\
\text { Maeda et ai. } 1996(44)\end{array}$ \\
\hline Adipsin & $\begin{array}{l}\text { Cook et al. } 1987(19) \\
\text { Choy et al. } 1992(16)\end{array}$ \\
\hline Agouti & Bultman et al. 1992 (10) \\
\hline Angiotensinogen & Cassis et al. 1988 (13) \\
\hline Insulin-like growth factor-1 (IGF-1) & $\begin{array}{l}\text { Doglio et al. } 1987(20) \\
\text { Chen et al. } 1996(15)\end{array}$ \\
\hline Interleukin-6 (IL-6) & $\begin{array}{l}\text { Fried et al. } 1998 \text { (25) } \\
\text { Mohamed-Ali et al.1998 (50) }\end{array}$ \\
\hline Leptin & Zhang et al. 1994 (79) \\
\hline Plasminogen activator inhibitor (PAl-1) & Shimomura et al. $1996(66)$ \\
\hline Prostaglandin $\mathrm{E}_{2}\left(\mathrm{PGE}_{2}\right)$ & Hyman et al. 1982 (36) \\
\hline Prostaglandin $\mathrm{I}_{2}\left(\mathrm{PG}_{2}\right)$ & Richelsen 1992 (61) \\
\hline Sex steroids & Bouloumie et al. 1994 (9) \\
\hline Transforming growth factor $\beta$ (TGF $\beta$ ) & $\begin{array}{l}\text { Richardson et al. } 1989(60) \\
\text { Sporn et al. } 1987(70)\end{array}$ \\
\hline Tumor necrosis factor $(\mathrm{TNF} \alpha)$ & Hotamisligil et al. 1993 (32) \\
\hline Vascular endothelial growth factor (VEGF) & Asano et al. $1997(6)$ \\
\hline
\end{tabular}

the development of atherosclerotic vascular diseases.

It is known that plasma adiponectin rapidly accumulates in the subendothelial space of the injured human artery $(53,56)$. In cultured cells, human recombinant adiponectin suppressed the attachment of monocytes to endothelial cells and the transformation of macrophages to form cells $(55,56,57)$. Besides, adiponectin dose-dependently inhibits TNF- $\alpha$ signalling pathway in human aortic endothelial cells as well as it reduces TNF- $\alpha$ production in macrophages $(53,77)$. Recently, it has been described that adiponectin acts as a platelet-derived growth factor$\mathrm{BB}$-binding protein and generally inhibits growth factor-induced proliferation and migration of vascular smooth muscle cells
(4). Adiponectin concentrations on human plasma have been directly related to HDL cholesterol levels and inversely related to von Willebrand factor levels (81). Altogether, these facts suggest the hypothesis that adiponectin acts as a protective factor for the cardiovascular system. Furthermore, it has been recently documented for the first time that elevated plasma adiponectin suppresses the development of atherosclerosis in vivo in apolipoprotein E-deficient mice (54).

\section{Leptin}

Leptin, the peptide product of the $a b$ gene was discovered in 1994 and it is secreted mainly by adipocytes (80). Lep- 
tin, a 167-amino acid polypeptide with a putative 21-amino acid signal sequence giving rise to a 146-aminoacid secreted polypeptide, acts through its specific receptors that exhibit an almost universal distribution (71). Leptin receptors exist in at least 6 isoforms. The so called "long form", $\mathrm{OB}-\mathrm{Rb}$, with one transmembrane domain and a long intracellular carboxy terminal tail, is thought to be the most important for transmitting the leptin signal in cells $(1,26,71)$. The OB-Ra, OB$\mathrm{Rc}, \mathrm{OB}-\mathrm{Rd}$ and $\mathrm{OB}-\mathrm{Rf}$ are prematurely terminated receptor proteins with short intracellular tails, and they are presumed to facilitate the transport of leptin across the brain-blood barrier. The OB-Re lacks the transmembrane domain and, therefore, it may function as a soluble receptor to bind and inactivate circulating leptin (41). Leptin receptors are found in a variety of tissues, but $\mathrm{OB}-\mathrm{Rb}$ is located predominantly in the hypothalamus.

Leptin is a lipostatic hormone that is released from adipose tissue and regulates the amount of body fat by reducing food intake and increasing energy expenditure through its action on the hypothalamus $(11,79)$. However, elevated serum leptin levels due to mutations in the leptin gene or with leptin resistance from mutations in the leptin receptor, are associated with profound obesity (45).

The results of recent studies have shown that leptin is not only a satiety hormone, but is also involved in the regulation of a number of very different physiological processes, such as reproduction and puberty (73), osteogenesis (72), hematopoiesis (18), angiogenesis (67), and regulation of blood pressure (39). Both clinical and experimental evidence supports the participation of leptin in blood pressure regulation. It has been shown that intracerebroventricular injection or chronic intravenous infusion of leptin increases peripheral resistance and blood pressure in normotensive rats $(14,65)$. These cardiovascular effects of leptin are at least partially mediated by stimulation of the sympathetic nervous system (31). Transgenic mice overexpressing leptin are characterised by hyperleptinemia, elevated blood pressure and sympathetic nerve hyperactivity (2). Although chronic effects of leptin seem to be predominantly prohypertensive (65), the fact that leptin did not acutely increase arterial pressure despite sympathetic activation suggested that it may activate counterregulatory mechanisms (31).

There are several arguments to suggest that leptin may decrease blood pressure. First, the role of this adipocyte-derived peptide on the vascular wall is evident since the presence of leptin receptors has been demonstrated in endothelial cells (67). Leptin is able to increase the production of endothelial nitric oxide in isolated blood vessels and, consequently to induce direct vasodilation through distinct endothelial mechanism $(28,42)$ that opposes the sympathetic-mediated pressor response (31). We and others have described the presence of leptin receptors in vascular smooth muscle cells (VSMCs) homogenates obtained from aorta of Wistar rats $(24,52)$. Second, the functionality of the leptin receptor was previously demonstrated in calcifying vascular cell (58) and aortic smooth muscle cells, in which leptin stimulates the cellular proliferation (52). On the basis of this finding, there are some recently emerging mechanisms that imply a closer relationship with the direct action of the vasoactive agonists on VSMCs. Among them, angiotensin (Ang) II (12) deserves particular attention because the renin-angiotensin-aldosterone system plays a major role in the 
pathophysiology of hypertension and related sequelae, such as cardiac hypertrophy, diastolic dysfunction, and heart failure. We recently proposed the hypothesis that leptin may present another vasodilating effect by interfering with the vascular responses induced by Ang II through OB-Rb. Our experiments have shown that physiological concentrations of leptin were able to specifically inhibit the Ang II-induced fast contraction in endothelium-denuded aortic rings from Wistar rats (24). This physiological effect was mediated by a classical intracellular mechanism of action. We observed that although no effect of leptin on basal intracellular free calcium concentration $\left(\left[\mathrm{Ca}^{2+}\right]_{i}\right)$ was observed, leptin was able to inhibit Ang II-induced calcium release from intracellular stores in cultured VSMCs of the aorta from Wistar rats (Fig. 1). Moreover, the same experiments were repeated on vascular preparations obtained from Zucker rats, with a mutation in the leptin receptor gene that results in the loss of its functional activity. In these conditions, a lack of effect of leptin on Ang II-mediated effects was observed. These results suggest that $\mathrm{OB}-\mathrm{Rb}$ are functional in the vascular wall of Wistar rats and provides a potential mechanistic explanation for obesity-associated hypertension (24). Together these results support the hypothesis that leptin plays a relevant role in modulating vasoregulatory function directly through $\mathrm{OB}-\mathrm{Rb}$ on the different cellular types of the vascular wall. Finally, it has also been shown that leptin induces natriuresis and diuresis by acting locally in the rat kidney (37) and it is able to increase insulin sensitivity in the whole body (68). Both peripheral mechanisms may also contribute to the antihypertensive action of leptin.
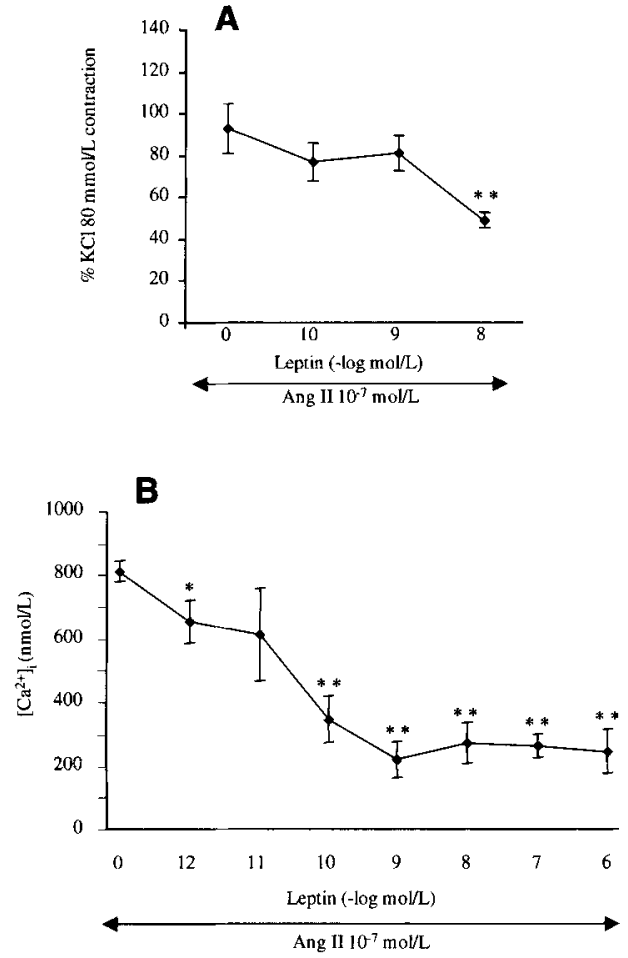

Fig. 1. Effect of different concentrations of leptin on $10^{-7} \mathrm{~mol} / \mathrm{l}$ Ang II -induced changes of tension of endothelium-denuded aortic rings $(A)$ and in intracellular calcium concentration ( $\left.\left[\mathrm{Ca}^{2+}\right]_{i}\right)$ of vascular smooth muscle cells (VSMCs) (B) from adult Wistar rats.

Aortic rings were preincubated for $30 \mathrm{~min}$ and VSMCs for $10 \mathrm{~min}$ with different concentrations of leptin. Values are the mean \pm SEM from 10-15 determinations/concentration. *, $\mathrm{P}<0.05$; *, $\mathrm{P}<$ 0.01 vs control response to ANG II (Adapted from reference 24 )

\section{Conclusions}

Obesity is a common background of the typical life style-related diseases, such as hypertension, although the mechanisms that link obesity with high blood pressure have not been elucidated. In this sense, adipose cells seem to play a more dynamic role than previously recognised in physiological mechanisms. There is 
already considerable evidence linking increased production of some adipocyte factors with the metabolic and cardiovascular complications of obesity. A significant inverse relationship between plasma adiponectin and leptin concentration has been recently described. While plasma adiponectin level was decreased in obesity (5), elevated plasma leptin levels and adipocyte $a b$ mRNA expression are strongly correlated with estimates of obesity $(1,47)$. The inversely related plasma levels of both adipokines suggest that both proteins have complementary and/or opposite roles on fat metabolism, energy balance, vascular tone and insulin sensitivity $(47,81)$. Whether hypoadiponectinemia and hyperleptinemia may work together to accelerate the development of the cardiovascular pathologies merits further investigation.

\section{Acknowledgements}

This work was supported in part by "Fundación de Aguas de Valencia".

A. FORTUÑO, A. RODRÍGUEZ, J. GÓMEZ-AMBROSI, G. FRÜHBECK y J. DÍEZ. El tejido adiposo como órgano endocrino: papel de la leptina y adiponectina en la patogénesis cardiovascular (minirrevisión). J. Physiol. Biochem., 59 (1), 51-60, 2003.

La obesidad es la más común de las enfermedades nutricionales de los países industrializados y está asociada con un aumento de la mortalidad y morbilidad cardiovascular. Sin embargo, las bases moleculares de esta asociación aún no se han clarificado. Recientes avances en la biología del tejido adiposo han permitido demostrar que además de almacenar energía, es también un órgano de secreción capaz de producir una amplia variedad de sustancias bioactivas entre las que se incluyen la leptina y la adiponectina. Ambas hormonas pueden influir tanto en la función como en la integridad estructural del sistema cardiovascular. La leptina, además de ser una señal de saciedad para el sistema nervioso central y estar relacionada con el metabolismo de la glucosa y de la insulina, desempeña también un papel en la regulación del tono vascular, como consecuencia de la amplia distribución de sus receptores funcionales en las células vasculares. Por otra parte, la adiponectina, proteína descrita más recientemente, parece jugar un papel protector en los modelos experimentales de daño vascular, en parte, porque es capaz de suprimir la unión de los monocitos a las células endoteliales, que es un paso fundamental en el proceso aterosclerótico. Existen suficientes evidencias que relacionan alteraciones de la producción de hormonas adipocitarias con las complicaciones cardiovasculares de la obesidad. En consecuencia, el avance en el conocimiento de las alteraciones en la función endocrina del tejido adiposo podría ayudar a entender el riesgo cardiovascular asociado a la obesidad.

Palabras clave: Adipocitos, Adiponectina, Enfermedades cardiovasculares, Leptina, Obesidad.

\section{References}

1. Ahima, R. S. and Flier, J. S. (2000): Annu. Rev. Pbysiol., 62, 413-437.

2. Aizawa-Abe, M., Ogawa, Y., Masuzaki, H., Ebihara, K., Satoh, N., Iwai, H., Matsuoka, N., Hayashi, T., Hosoda, K., Inoue, G., Yoshimasa, Y. and Nakao, K. (2000): J. Clin. Invest, 105, 1243-1252.

3. Alpert, M. A. (2001): Am. J. Med. Sci. 321, 225236.

4. Arita, Y., Kihara, S., Ouchi, N., Maeda, K., Kuriyama, H., Okamoto, Y., Kumada, M., Hotta, K., Nishida, M., Takahashi, M., Nakamura, T., Shimomura, I., Muraguchi, M., Ohmoto, Y., Funahashi, T. and Matsuzawa, Y. (2002): Circulation, 105, 2893-2898.

5. Arita, Y., Kihara, S., Ouchi, N., Takahashi, M., Maeda, K., Miyagawa, J., Hotta, K., Shimomura, I., Nakamura, T., Miyaoka, K., Kuriyama, H., Nishida, M., Yamashita, S., Okubo, K., Matsubara, K., Muraguchi, M., Ohmoto, Y., Funahashi, T. and Matsuzawa, Y. (1999): Biochem. Biopbys. Res. Commun., 257, 79-83. 
6. Asano, A., Morimatsu, M., Nikami, H., Yoshida, T. and Saito, M. (1997): Biochem. J., 328, 179183.

7. Berg, A.H., Combs, T. P., Du, X., Brownlee, M. and Scherer, P.E. (2001): Nat. Med., 7, 947-953.

8. Boehringer, K., Beretta-Piccoli, C., Weidmann, P., Meier, A. and Ziegler, W. (1982): Hypertension, 4, 697-702.

9. Bouloumie, A., Valet, P., Dauzats, M., Lafontan, M. and Saulnier Blache, J.S. (1994): Am. J. Physiol., 267, C926-931.

10. Bultman, S.J., Michaud, E.J. and Woychik, R.P. (1992): Cell, 71, 1195-1204.

11. Campfield, L.A., Smith, F.J., Guisez, Y., Devos, R. and Burn, P. (1995): Science, 269, 546-549.

12. Cassis, L.A. (2000): Curr. Hypertens. Rep., 2, 132-138.

13. Cassis, L.A., Saye, J. and Peach, M.J. (1988): Hypertension, 11, 591-596.

14. Casto, R.M., VanNess, J.M. and Overton, J.M. (1998): Neurosci. Lett., 246, 29-32.

15. Chen, H., Charlat, O., Tartaglia, L.A., Woolf, E.A., Weng, X., Ellis, S.J., Lakey, N.D., Culpepper, J., Moore, K.J., Breitbart, R.E., Duyk, G.M., Tepper, R.I, and Morgenstern, J.P. (1996): Cell, 84, 491-495.

16. Choy, L.N., Rosen, B.S. and Spiegelman, B.M. (1992): J. Biol. Chem., 267, 12736-12741.

17. Cianflone, K.M., Sniderman, A.D., Walsh, M.J., $\mathrm{Vu}$, H.T., Gagnon, J. and Rodríguez, M.A. (1989): J. Biol. Chem., 264, 426-430.

18. Cioffi, J.A., Shafer, A.W., Zupancic, T.J., SmithGbur, J., Mikhail, A., Platika, D. and Snodgrass, H.R. (1996): Nat. Med., 2, 585-589.

19. Cook, K.S., Min, H.Y., Johnson, D., Chaplinsky, R.J., Flier, J.S., Hunt, C.R. and Spiegelman, B.M. (1987): Science, 237, 402-405.

20. Doglio, A., Dani, C., Fredrikson, G., Grimaldi, P. and Ailhaud, G. (1987): EMBO J., 6, 40114016.

21. Eckel, R.H., Barouch, W.W. and Ershow, A.G. (2002): Circulation, 105, 2923-2928.

22. Flier, J.S. (1995): Cell, 80, 15-18.

23. Flier, J.S. and Maratos Flier, E. (1998): Cell, 92, 437-440.

24. Fortuño, A., Rodríguez, A., Gómez-Ambrosi, J., Muñiz, P., Salvador, J., Díez, J. and Frühbeck, G. (2002): Endocrinology, 143, 3555-3560.

25. Fried, S.K., Bunkin, D.A. and Greenberg, A.S. (1998): J. Clin. Endocrinol. Metab., 83, 847-850.

26. Friedman, J.M. and Halaas, J.L. (1998): Nature, 395, 763-770.

27. Frohlich, E.D., Messerli, F.H., Reisin, E. and Dunn, F.G. (1983): Hypertension, 5, 71-78.

28. Frühbeck, G. (1999): Diabetes, 48, 903-908.
29. Frühbeck, G., Gómez Ambrosi, J., Muruzábal, F.J. and Burrell, M.A. (2001): Am. J. Physiol. Endocrinol. Metab., 280, 827-847.

30. Goldhaber, S.Z., Grodstein, F. and Stampfer, M.J. (1997): J. Am. Med. Assoc., 277, 642-645.

31. Haynes, W.G., Morgan, D.A., Walsh, S.A., Mark, A.L. and Sivitz, W.I. (1997): J. Clin. Invest., 100, 270-278.

32. Hotamisligil, G.S., Shargill, N.S. and Spiegelman, B.M. (1993): Science, 259, 87-91.

33. Hotta, K., Funahashi, T., Arita, Y., Takahashi, M., Matsuda, M., Okamoto, Y., Iwahashi, H., Kuriyama, H., Ouchi, N., Maeda, K., Nishida, M., Kihara, S., Sakai, N., Nakajima, T., Hasegawa, K., Muraguchi, M., Ohmoto, Y., Nakamura, T., Yamashita, S., Hanafusa, T. and Matsuzawa, Y. (2000): Arterioscler. Thromb. Vasc. Biol., 20, 1595-1599.

34. Hotta, K., Funahashi, T., Bodkin, N.L., Ortmeyer, H.K., Arita, Y., Hansen, B.C. and Matsuzawa, Y. (2001): Diabetes, 50, 1126-1133.

35. Hu, E., Liang, P. and Spiegelman, B.M. (1996): J. Biol. Chem., 271, 10697-10703.

36. Hyman, B.T., Stoll, L.L. and Spector, A.A. (1982): Biochim. Biophys. Acta, 713, 375-385.

37. Jackson, E.K. and Herzer, W.A. (1999): Am. J. Physiol., 277, F761-765.

38. Johnson, A.L., Cornoni, J.C., Cassel, J.C., Tyroler, H.A., Heyden, S. and Hames, C.G. (1975): Am. J. Cardiol., 35, 523-530.

39. Kokot, F., Adamczak, M., Wiecek, A. and Cieplok, J. (1999): Kidney Blood Press. Res., 22, 154-160.

40. Kumada, M., Kihara, S., Sumitsuji, S., Kawamoto, T., Matsumoto, S., Ouchi, N., Arita, Y., Okamoto, Y., Shimomura, I., Hiraoka, H., Nakamura, T., Funahashi, T. and Matsuzawa, Y. (2003): Arterioscler. Thromb. Vasc. Biol, 23, 8589.

41. Lee, G.H., Proenca, R., Montez, J.M., Carroll, K.M., Darvishzadeh, J.G., Lee, J.I. and Friedman, J.M. (1996): Nature, 379, 632-635.

42. Lembo, G., Vecchione, C., Fratta, L., Marino, G., Trimarco, V., díAmati, G. and Trimarco, B. (2000): Diabetes, 49, 293-297.

43. Loskutoff, D.j. and Samad, F. (1998): Arterioscler. Thromb. Vasc. Biol.,18, 1-6.

44. Maeda, K., Okubo, K., Shimomura, I., Funahashi, T., Matsuzawa, Y. and Matsubara, K. (1996): Biochem. Biophys. Res. Commun., 221, 286-289.

45. Mark, A.L., Correia, M.L.G., Rahmouni, K. and Haynes, W.G. (2002): J. Hypertens., 20, 12451250. 
46. Matsubara, M., Marioka, S. and Katayose, S. (2002): J. Clin. Endocrinol. Metab., 87, 27642769.

47. Matsubara, M., Maruoka, S. and Katayose, S. (2002): Eur. J. Endocrinol., 147, 173-180.

48. Messerli, F.H., Christie, B., DeCarvalho, J.G., Aristimuno, G.G., Suarez, D.H., Dreslinski, G. R. and Frohlich, E.D. (1981): Arch. Intern. Med., 141, 81-85.

49. Mikhail, N., Golub, M.S. and Tuck, M.L. (1999): Prog. Cardiovasc. Dis. 42, 39-58.

50. Mohamed Ali, V., Pinkney, J.H. and Coppack, S.W. (1998): Int. J. Obes. Relat. Metab. Disord., 22, 1145-1158.

51. Nakano, Y., Tobe, T., Choi Miura, N.H., Mazda, T. and Tomita, M. (1996): J. Biochem. (Tokyo), 120, 803-812.

52. Oda, A., Taniguchi, T. and Yokoyama, M. (2001): Kobe. J. Med. Sci., 47, 141-150.

53. Okamoto, Y., Arita, Y., Nishida, M., Muraguchi, M., Ouchi, N., Takahashi, M., Igura, T., Inui, Y., Kihara, S., Nakamura, T., Yamashita, S., Miyagawa, J., Funahashi, T. and Matsuzawa, Y. (2000): Horm. Metab. Res., 32, 47-50.

54. Okamoto, Y., Kihara, S., Ouchi, N., Nishida, M., Arita, Y., Kumada, M., Ohashi, K., Sakai, N., Shimomura, I., Kobayashi, H., Terasaka, N., Inaba, T., Funahashi, T. and Matsuzawa, Y. (2002): Circulation, 106, 2767-2770.

55. Ouchi, N., Kihara, S., Arita, Y., Maeda, K., Kuriyama, H., Okamoto, Y., Hotta, K., Nishida, M., Takahashi, M., Nakamura, T., Yamashita, S., Funahashi, T. and Matsuzawa, Y. (1999): Circulation, 100, 2473-2476.

56. Ouchi, N., Kihara, S., Arita, Y., Nishida, M., Matsuyama, A., Okamoto, Y., Ishigami, M., Kuriyama, H., Kishida, K., Nishizawa, H., Hotta, K., Muraguchi, M., Ohmoto, Y., Yamashita, S., Funahashi, T. and Matsuzawa, Y. (2001): Circulation, 103, 1057-1063.

57. Ouchi, N., Kihara, S., Arita, Y., Okamoto, Y., Maeda, K., Kuriyama, H., Hotra, K., Nishida, M., Takahashi, M., Muraguchi, M., Ohmoto, Y, Nakamura, T., Yamashita, S., Funahashi, T. and Matsuzawa, Y. (2000): Circulation, 102, 12961301.

58. Parhami, F., Tintut, Y., Ballard, A., Fogelman, A.M. and Demer, L.L. (2001): Circ. Res., 88, 954960.

59. Rader, D.J. (2000): New Eng. J. Med., 343, 1179 1182.

60. Richardson, R.L., Wright, J.T., Kim, J.W. and Hausman, G.J. (1992): Growth Dev. Aging, 56, 149-157.
61. Richelsen, B. (1992): Prostaglandins Leukot. Essent. Fatty Acids, 47, 171-182.

62. Rocchini, A.P., Moorehead, C., Katch, V., Key, J. and Finta, K.M. (1992): Hypertension, 19, 615620.

63. Saltiel, A.R. (2001): Nat. Med., 7, 887-888.

64. Scherer, P.E., Williams, S., Fogliano, M., Baldini, G. and Lodish, H.F. (1995): J. Biol. Chem., 270, 26746-26749.

65. Shek, E.W., Brands, M.W. and Hall, J.E. (1998): Hypertension, 31, 409-414.

66. Shimomura, I., Funahashi, T., Takahashi, M., Maeda, K., Kotani, K., Nakamura, T., Yamashita, S., Miura, M., Fukuda, Y., Takemura, K., Tokunaga, K. and Matsuzawa, Y. (1996): Nat. Med., 2, 800-803.

67. Sierra-Honigmann, M.R., Nath, A.K., Murakami, C., García-Cerdeña, G., Papapetropoulos, A., Sessa, W.C., Madge, L. A., Schechner, J.S., Schwabb, M.B., Polverini, P.J. and FloresRiveros, J.R. (1998): Science, 281, 1683-1686.

68. Sivitz, W.I., Walsh, S.A., Morgan, D.A., Thomas, M.J. and Haynes, W. G. (1997): Endocrinology, 138, 3395-3401.

69. Spiegelman, B.M. and Flier, J.S. (1996): Cell, 87, 377-389.

70. Sporn, M.B., Roberts, A.B., Wakefield, L.M. and de Crombrugghe, B. (1987): J. Cell. Biol., 105, 1039-1045.

71. Tartaglia, L.A. (1997): J. Biol. Chem., 272, 60936096.

72. Thomas, T., Gori, F., Khosla, S., Jensen, M.D., Burguera, B. and Riggs, B.L. (1999): Endocrinology, 140, 1630-1638.

73. Wauters, M., Considine, R.V. and Van Gaal, L.F. (2000): Eur. J. Endocrinol., 143, 293-311.

74. Weir, M.R., Reisin, E., Falkner, B., Hutchinson, H. G., Sha, L. and Tuck, M. L. (1998): Am. J. Hypertens., 11, 914-920.

75. Weyer, C., Funahashi, T., Tanaka, S., Hotta, K., Matsuzawa, Y., Pratley, R. E. and Tataranni, P. A. (2001): J. Clin. Endocrinol. Metab., 86, 19301935.

76. Yamauchi, T., Kamon, J., Waki, H., Terauchi, Y., Kubota, N., Hara, K., Mori, Y., Ide, T., Murakami, K., Tsuboyama Kasaoka, N., Ezaki, O., Akanuma, Y., Gavrilova, O., Vinson, C., Reitman, M. L., Kagechika, H., Shudo, K., Yoda, M., Nakano, Y., Tobe, K., Nagai, R., Kimura, S., Tomita, M., Froguel, P. and Kadowaki, T. (2001): Nat. Med., 7, 941-946.

77. Yokota, T., Oritani, K., Takahashi, I., Ishikawa, J., Matsuyama, A., Ouchi, N., Kihara, S., Funahashi, T., Tenner, A. J., Tomiyama, Y. and Matsuzawa, Y. (2000): Blood, 96, 1723-1732. 
78. Zemel, M.B. (1998): Mol. Cell Biochem., 188, 129-136.

79. Zhang, R. and Reisin, E. (2000): Am. J. Hypertens., 13, 1308-1314.

80. Zhang, Y., Proenca, R., Maffei, M., Barone, M., Leopold, L, and Friedman, J.M. (1994): Nature, $372,425-432$.
81. Zoccali, C., Mallamaci, F., Tripepi, G., Benedetto, F.A., Cutrupi, S., Parlongo, S., Malatino, L.S., Bonanno, G., Seminara, G., Rapisarda, F., Fatuzzo, P., Buemi, M., Nicocia, G., Tanaka, S., Ouchi, N., Kihara, S., Funahashi, T. and Matsuzawa, Y. (2002), J. Am. Soc. Nephrol, 13, 134141. 